\title{
FEATURES OF INTRODUCTION OF THE SYSTEM APPROCH TO THE STATE POLICY
}

\begin{abstract}
Marta Karpa ${ }^{1}$, Oleksandr Akimov ${ }^{2}$, Liudmyla Akimova ${ }^{3}$
${ }^{1}$ Doctor of Science in Public Administration, Associate Professor, Professor of the Department of Public Administration and Administration, Hryhorii Skovoroda University in Pereiaslav, Pereiaslav, Ukraine, email: marta.karpa@ukr.net,ORCID: https://orcid.org/0000-0001-8141-4894

${ }^{2}$ Doctor of Science in Public Administration, Associate professor, Honored Economist of Ukraine, Professor of the Department of Public Administration, Interregional Academy of Personnel Management, Kyiv, Ukraine, e-mail: 1970aaa@ukr.net, ORCID: https://orcid.org/0000-0002-9557-2276

${ }^{3}$ Doctor of Science in Public Administration, Ph.D. in Economics, Professor, Honored Worker of Education of Ukraine, Professor of the Department of Finance and Economic Security, National University of Water and Environmental Engineering, Rivne, Ukraine, e-mail: l_akimova@ukr.net, ORCID: https://orcid.org/0000-0002-2747-2775
\end{abstract}

Abstract. Public policy analysis began to be actively addressed in the middle of the twentieth century. The main motives for the introduction of public policy in these times were considered "public interest", "public good". The content of these concepts is interpreted as follows: "a public good is what is produced by the state, not by the market" and other globalization movements. Researchers record the growth of conflict between the state and society. Therefore, scientists should interpret the concept of "public policy" as a systemic phenomenon in order to develop a single clear theoretical and methodological base, which will theoretically approve a universal statement of the foundations of public policy. The relevance of the topic of this study is indicated by the following facts: the lack of a procedure for implementing public policy, ineffective legal regulation of relations between society and the state, monopoly concentration of most powers in the hands of certain state institutions, unilateral adoption of most power and managerial decisions.

Keywords: systematic approach, public policy, subject of public policy, field of public policy.

JEL Classification: D78, F68, G18, G28, I28, J18

Formulas: 0; fig.: 0; tabl.: 0; bibl.: 21

Introduction. The purpose of this article is to analyze the concept of "political politics" using a systematic approach. The object of the research is the sphere of public policy implementation. The subject of the research is the components of public policy as a systemic concept: the object and subject of political policy, connections between them, methods of implementing public policy. Research objectives: using the system-element approach to determine the main elements of the phenomenon of "public policy"; to characterize the process of public policy, its functions and its main components; determine the environment in which public policy is implemented; consider the subjects of public policy from the standpoint of the division into state and public $[2,3,4]$.

Literature Review. A lot of domestic and foreign scientists and practitioners turned to the study of the problems of the formation and organization of public policy. W. Parsons, G. Kolbech, Adam Smith, James Mill, Torrance, William Dunn, Leslie Pal, Paul Brown, Louis Gunn, Thomas Dye, John Bryson and others have made a great contribution to the development of public policy. V. Averyanov, I. Kozyura, I. Gritsyak, N. Nizhnik, E. Afonin, A. Obolensky, G. Sitnik, S. Virovy, O. are taking civil society into account world experience and modern practice.

The formation and organization of public authority from the standpoint of the functioning of civil society requires more and more attention of researchers. The 
issue of the origin, formation and organization of public policy is the object of active scientific discussions. Therefore, the research concerns the analysis of the concept of "public policy" from the standpoint of a systemic approach, which will allow to study this process as a systemic phenomenon, structure it, and form a new model of relations between society and government.

Aims. The novelty of the research lies in the use of a systematic approach to the concept of "public policy". In particular, it is proposed to consider the phenomenon of "public policy" as a systemic phenomenon, with the presence of structural units elements of the system. Taking into account the systemic and elementary aspect of the systemic approach, it is indicated that the main elements of public policy are the subject, object and subject of public policy, connections between them, methods of policy implementation. It is indicated that the subject of public policy is public interest, and the subjects of public policy should be considered state (state institutions, enterprises) and public entities (public formations, political parties, business organizations).

The author characterizes the concept of "public policy" and the concept of "public field", its indicators. The methodological and general scientific meaning of the presented material makes it possible to move from an abstract understanding of the phenomenon of "public policy" to the knowledge of its specific components. Analysis of public policy as a systemic phenomenon is also essential. using the following basic approaches as system-element, system-functional, system-structural.

Methods. Using the method of analysis, a study was carried out on the phenomenon of political politics. With the help of a systematic approach, the concept of public policy is defined as a systemic object, and a study of its content elements is carried out. Determine the main elements of the "public policy" phenomenon using the systemic-elementary approach.The political environment as an external system of influencing politics is studied using abstract methods and systemic methods.

It is proposed to consider the phenomenon of "public policy" as a systemic phenomenon, with the presence of structural units - elements of the system. Taking into account the systemic and elementary aspect of the systemic approach, it is indicated that the main elements of public policy are the subject, object and subject of public policy, the connections between them, and methods of policy implementation.

Results. The study of the public sphere goes back to ancient times. It is known that the ancient Romans introduced the concept of public and private, which are still being studied by political scientists, economists, and lawyers. After all, there is no clear division between the public and the private. Therefore, at the junction of these concepts, a conflict of interests arises: public and private, state and public. Practice shows that the penetration of public policy takes place in almost all spheres of society, including those that were once considered private, for example, education, health care, social security, and the like.

Already in the post-war era, liberal ideas about the goals of developing and implementing public policy were asserted on the basis that the role of the state should be to manage the "public" and its problems in order to solve those problems of public life that are beyond the power of the market. Research in the field of relations 
between society and the state in the twentieth century more and more scientists and practitioners began to study. The science "Public Policy Analysis" is quite developed in the West; the subject of study is the processes of formation and implementation of public policy [5].

There are many concepts, their formulations, processes, indicate the unrestrained process of entering the public in the development of policy. For example, the definition of politics in the classical form of the struggle for power operates with the concepts of public interest, social needs: "politics is the sphere of relations between various social groups and individuals regarding the use of public authorities to realize their socially significant interests and needs" [6]. "Public" means those aspects of human activity that require government or public regulation, intervention, or at least joint action [7].

A complete phenomenon in the process of the origin of public policy is public power, the main components of which are state and self-governing. In solving many issues, these components act in a comprehensive manner, taking into account their capabilities (powers). It is very difficult to single out one of them and carry out its reforms, because they are often linked by common tasks, certain funding, etc. Therefore, public authorities should also be considered only taking into account consistency, as its basic characteristics. The main features of public power, as well as public politics, are: the possibility of expressing the will of the people (taking into account public opinion, developing a mechanism for such accounting), serving the government to the people, interaction between the government and the people on an equal footing. "... The public, - according to the definition of the world famous German social philosopher J. Habermas, is an environment in which a polyphonic process of creating opinions takes place, where strength is replaced by mutual understanding" [8].

Consequently, the concept of "public policy" should be interpreted as a systemic phenomenon, where each element is characterized by the characteristic features of pidsystemicity, feedbacks, causal relationships, etc. logical ordering of the entire set of concepts / categories using a systematic approach [9].

The main objectives of the systems approach in the context of this study are as follows:

- to define and study individual categories as structural parts of the concept of "public policy" (systemic and elementary aspect);

- to identify causal relationships between the components of the phenomenon of public policy (systemic and structural aspect).

Since the systematic approach can be used, moving in the study from the abstract to the concrete, let us turn to the form of systematization proposed by the scientist A. Deineko [10], according to which the phenomenon of public policy should be considered as a set of such concepts as - object, subject, subject, connections between them, methods. Let's carry out the definitions of each of these elements.

The main objectives of the systems approach in the context of this study are as follows: 
- to define and study individual categories as structural parts of the concept of "public policy" (systemic and elementary aspect);

- to identify causal relationships between the components of the phenomenon of public policy (systemic and structural aspect).

The subjects of public policy are state and public political subjects. All entities are characterized by the initiation, development and implementation of policies for specific interests. In this context, "politicism" should be interpreted as a sign of influencing at different social and administrative levels. In more detail, the scope of activities of public entities "objects can be grouped as follows:

- the sphere of civil society - characterized by the activities of a mass subject: mass movements, political parties, public formations, protests, and the like;

- the sphere of business - characterized by the activities of business associations, large industrial groups, lobbies, and the like;

- the sphere of information - characterized by a significant influence on the mass political consciousness.

The activity of state political subjects is determined by the functioning of state authorities, institutions, organizations, enterprises. The main feature of the subjects from the standpoint of building a civil society is their equality in decision-making, professionalism, and the availability of resources for policy implementation.

About "the object of public policy is the development of policy by all sub" objects on an equal footing. An important condition for the implementation of policy is the consideration of all interests. It is necessary to take into account the interests of the whole society or its individual parts (according to various criteria - territorial, age, gender, professional, etc.). So, the result of public policy should be obtaining the consent of all actors. Authors Karl Patton and David Sawicki consider public policy as a way to create and implement complex programs for solving socially significant problems [11]. Consequently, there is a need for an interpretation of the concept of public (public) interest. There is an assumption that the public interest itself is the subject of public policy. After all, taking it into account is a prerequisite for the development of public policy. The main difficulty in forming the definition of public interest is its content, since only taking into account the interests of all subjects of "objects of public policy will form the basis for this. How to take into account the interests of all participants in public policy - state and public institutions? After all, this requires equal positions. Here you should to turn to the concept of "connections." Connections act as a link between the elements of public policy that ensure its functioning, the decision-making process. There are many options for connections: subject - subject, subject - object, subject - subject, etc. The concept of public policy should be considered not only from the standpoint of its administrative load, but from the standpoint of its administrative function [12]. Links between the elements should be formed [13], taking into account the subordination and coordination forms of building relationships.

One of the principles of building links is to ensure communication between subjects of public policy. It is the communication relations that contribute to the reliable, quick transfer of the prerequisites for making a decision from one subject to 
another. The coordination process is inherent not so much a managerial character as an advisory one. Therefore, the main methodological task in this context is the settlement of the issue of equal provision by the methods of the state and public entity, taking into account feedbacks. The main features of connections are: characterized as a connecting link between elements, carries communicative features; purposeful, ensure integrity, functionality, determine the quality state of the elements of public policy $[20,21]$. They arise at all levels of public policy, between various elements and components, and theoretically reflect an attempt to link the functions of public policy with its internal properties and qualities. A method is a set of techniques, methods, tools used for policy development. In the context of using a systematic approach, public policy methods should be studied as a system of means for making and transmitting decisions, monitoring their implementation, the possibility of adjustments, the availability of the necessary material, information, human and other resources. Society constantly generates conflicts, for the settlement of which it is necessary to conclude transactions. Therefore, the main instruments for regulating disputes between the state and society should be consultations, negotiations, public hearings, round tables and other processes of agreements with the state that are open to society. "Public administration - as defined by George G. Sebine and Thomas L. Thorson, is primarily a system of institutions, designed to regulate public opinion and debate, and take into account opposite requirements in order to develop an effective policy" [14].

Discussion. The field of public policy can be defined as a field of activity for the implementation of politics, its visible part, transparent, open, in which the activities of all subjects of politics are legalized. For a broader study of this period, you need to turn to sociological sciences [20,21]. After all, the field of politics can always subordinate the problems of social research to its own political logic. For sociologists, a field is a place and a way to implement a certain social game, and a political field is a set of political positions involved in the struggle for a monopoly of legitimate symbolic violence, the goal is monopoly disposal of state capital [15]. The field of public policy can be defined as a space in which subjects fight for the legitimate symbolic control of people's behavior in their public life by imposing their means of perception, assessment and expression of the socio-political differentiation of society [16]. The main criteria for determining the public field can be considered: the spheres of the implementation of public policy, their legitimacy, the delimitation of the field into state and public and the definition of a common space (public field) for the implementation of public policy [17-19].

Conclusions. Summing up, we can note the main features inherent in public policy:

- a large number of political actors - state and public. Actors are characterized by the initiation, development and implementation of policies for specific interests. Public policy covers public policy, as well as policies that can be implemented by nongovernmental organizations, public structures, the private sector;

- interaction between them on the basis of parity, equality. It is through interaction that the connections and methods of policy implementation are manifested; 
- alignment of interests, competition, struggle.

As the main result, we highlight the following theses:

- the phenomenon of "public policy" should be considered a systemic phenomenon, with the presence of structural units - elements of the system;

- using the system-element aspect of the systemic approach, it has been established that the main elements of public policy are the subject, object and subject of public policy, connections between them, methods of policy implementation;

- the main characteristics of public policy are determined by a large number of subjects and the coordination of their interests. It is indicated that the subject of public policy is public interest;

- subjects of public policy should be considered state (state institutions, enterprises) and public entities (public formations, political parties, business organizations);

- the public field is designated as a space in which public policy is carried out, its characteristics and indicators for measurement are indicated;

- the source of origin of public policy is public authority, whose activity can be considered a systemic phenomenon of the highest level;

- with the help of the system-functional aspect of the system approach, the main functions that public policy performs in the life of society are determined.

This study can serve as the basis for further scientific developments in the plane of various aspects of the systems approach, as well as push scientists to the possibility of using other elements of philosophical research, such as the method of abstraction, dialectical materialistic method and other methodological approaches to the phenomenon of "public policy".

Author contributions. The authors contributed equally.

Disclosure statement. The authors do not have any conflict of interest.

References:

1. Parsons, V. (2006), Public policy: An introduction to the theory and practice of policy analysis / V. Parsons, M: house "Kiev-Mohyla Academy", 2006, 549 p., P.29.

2. Karpa, M. (2017), Formation of competencies of public authorities: territorially-oriented approach, Efektyvnist derzh.upravlennia (text): zb.nauk.pr. LRIPA NAPA, Issue 3, pp.213-222.

3. Akimov, O. (2015), Formation of professional civil service in Ukraine: legal principles Public administration: theory and practice, 1 (13).

4. Akimov, O. (2018), The concept of systemogenesis of professional activity of civil servants. Investments: practice and experience (23). pp. 133-138.

5. Demyanchuk, A.P. (2007), "State policy" and "public policy": a variant of the transitional period, Scientific notes, No. 18, p.32.

6. Political science textbook for university students. / Ed. A.V. Babkina, V.P. Humpbacked, Moscow, Publishing Center "Academy", 1998, P.6.

7. Parsons, V. (2006), Public policy: An introduction to the theory and practice of policy analysis / V. Parsons, M: house "Kiev-Mohyla Academy", 2006, 549 p., P.23.

8. Habermas J. Democracy, reason, morality. M, 1995, P. 40.

9. Markina, I.A. (2001), Methodology of modern management: monograph, Moscow, Higher school, 311 p., P.61.

10.Deineko, A. (1971), Methodological problems of production management science, Moscow, Nauka, pp. 200-202.

11.Carl V. Patton, David S. Savicki. (1993), Basic Methods of Policy Analysis and Planning. Englewood Cliffs, NJ: Prentice Hall, P.5.

12.Sebine George G., Thorson Thomas L. History of Political Thought . Moscow, Osnovy, 1997. pp. 650651. 
13.Belyaeva, N. (2008), Subject field of public policy [Electronic resource], SU-HSE, Moscow,Access mode: http://www.hse.ru.

14.Shmatko, N.A. (2001). The phenomenon of public policy, Sociological studies, No. 7, pp. 106-112.

15.Karpa, M. (2017), Status of the civil servant: functional, organizational and competence aspects, State building: zb.nauk.pr. DRIPA NAPA, № 1/2017, URL: http://www.kbuapa.kharkov.ua/e-book/db/20171/doc/3/03.pdf.

16. Akimov, O. (2016), Functional factors of systemogenesis of professional activity of civil servants. Investments: practice and experience (24). pp. 68-74.

17.Giddens, A. (1984), The constitution of society: outline of the theory of structuration. Cambridge: Polity Press, 1984. P.74.

18.Karpa, M. (2017), Subject competence of public authorities, Actual problems of public administration: collection. science. etc. ORIPA / [head. ed. Izga, M.], Issue 3 (71), Odessa, ORIPA NAPA, pp. 50-56.

19.Akimov, O. (2016), Professional activity of civil servants and officials of local self-government: psychological aspects of personnel management. Public administration and local self-government (3). pp. 106-113.

20.Public administration. English-Ukrainian dictionary of terms: textbook. way. / K.O. Vashchenko, R.G. Shchokin, E.A. Romanenko, L.M. Akimova [ed.]. Kyiv: PJSC "Interregional Academy of Personnel Management", 2020, 232 p. Public administration; issue 4.

21.Public administration. Civil servant's desk book and politics. Conceptual and terminological dictionary / KO Vashchenko, RG Shchokin, EA Romanenko, LM Akimova [ed.]. - Kyiv: PJSC "Interregional Academy of Personnel Management", 2020, 764 p. Public administration; issue 3.

22.Mihus, I., Greben S. (2020). Modern approaches to the essence and forms of public administration. Public administration in the digital economy. DOI: https://doi.org/10.36690/PADE. 